\title{
An Association of Cigarette Smoking with Recurrent Subareolar Breast Abscess
}

\author{
PETER SCHAFER, CHAHSTAN FURRER AND BERNADETTE MERIMLOD
}

\begin{abstract}
Schäfer P (Department of Gynaecology, University Hospital of Geneva, 24 rue Micheli-du-Crest, 1211 Genéve 4, Switzerland), Furrer $C$ and Merraillod B. An association of cigarette smoking with recurrent subareolar breast absecoss, International Joumal of Epiderniolagy 1888, 17: 810-813.

In a series of 60 patients suffering from recurrent subereolar breast abscoss (RSBA) heavy cigarette smoking was found at an unusually high frequency compared to a comtrol group. In contrast with findings reported in the literature no relation was found with parity, oral contreceptive use or nipple retrection.

The strong aseociation of cigarette smoking and RSBA with a relative risk of $9.2(3.6-23.5)$ for a light smoker and of 26.4 (9.9-70.2) for a heavy smoker counterbalances possible bies introduced by the retrospective analysis and by the hospltal control group.

The pethogenesis of RSBA is still not established. Clgarette smoking could have elther a direct toxic effect on the retroareolar lactiferous ducts or an indirect effect via hormonal stimulation of the breast secretion; both hypothes could explain the recurrent aspect of the disease.
\end{abstract}

Recurrent subareolar breast abscess (RSBA) is a common disease in younger women, although very little attention has been paid to it in the literature. RSBA is a non-puerperal mastitis whose pathogenesis has still not been established. ${ }^{1-3}$

RSBA is clinically ${ }^{2,3}$ and histologically ${ }^{47}$ a well characterized disease. It is not related to pregnancy and lactation and often begins as an inflammation located in the subareolar area which then develops into a small abscess at the edge of the areola. When it is incised and drained or spontaneously drains, the process seemingly subsides, only to flare up again in the same region after a few months. This cycle may be repeated over several years. A fistula, situated at the border of the areola develops in many patients. Aerobes and anaerobes are frequently present. .-11 $^{-11}$

RSBA is histologically characterized by the total absence of abnormal intraductal proliferation. Ducts lying beneath the nipple are lined with a stratified squamous epithelium which is otherwise limited to the intramanillary portion of the ducts, and plugged by keratinous debris. At some point there is a disruption of the walls of these ducts which communicate with the subarcolar abscess.

RSBA has to be distinguished from other forms of non-puerperal mastitis, as ductectasia, ${ }^{12}$ granuloma-

Department of Gynecology, University Hospital of Geneva, 24 rue Micheli-du-Crest, 1211 Genźve 4, Switzerland. tous mastitis ${ }^{13}$ and inflammatory cysts situated in the subareolar region.

By looking for common features in patients with RSBA, heavy cigarette smoking was found at an unusually high frequency. In the present report data relating cigarette smoking to the frequency of RSBA are presented and possible explanations of this correlation are discussed.

\section{PATIENTS AND METHODS \\ Cases}

Between September 1978 and June 1986, 60 patients with RSBA as defined by Johnsen ${ }^{2}$ were registered at the breast disease clinic of the department of gynaecology and obstetrics of the Geneva University Hospital. Twenty-five patients presented primary lesions, 18 patients presented with recurrent abscesses without fistula and 17 more presented with chronic fistulas. Their median age was 34 years. All patients were submitted to prolonged treatment with antibiotics, combined in 34 cases with incisional or excisional surgery. Only two patients have been lost during the follow-up.

\section{Controls}

Smoking habits of Swiss women have changed significantly over the last decade. ${ }^{14}$ The proportion of moderate smokers among all smokers decreased whereas the proportion of heavy smokers has 
increased. ${ }^{14}$ This evolution was less pronounced in certain subgroups, particularly for women originating from foreign countries living in Geneva.

It was therefore necessary to chose as controls, patients of the same origin who were seen in the same year. Five age-matched control patients hospitalized for non-puerperal, benign gynaecological disease were registered for every case.

Smoking habits were recorded routinely for all cases and controls at the first visit; the information obtained was insufficient to establish the pack-years-rate. Smokers were categorized according to the number of cigarettes smoked per day.

The following variables were analysed: parity, contraception by IUD, oral contraceptive use, nipple retraction and smoking habits.

\section{Statistics}

The data were analysed with stepwise logistic regression for matched sets using the program MATCH, ${ }^{15}$ which preserves the matching in the analysis and involves the fitting of models for specified sets of variables. We used variables thought to influence the risk of RSBA.

\section{RESULTS}

The youngest patient was 15 and the oldest was 70 years old; six patients were post-menopausal. Twentyfour patients were using oral contraceptives or had been using oral contraceptives within the five years before diagnosis. One postmenopausal patients was being treated with conjugated oestrogens. Seventeen patients had never been pregnant, 35 patients had given birth to one or more children; there was no particular anamnestic notion of breastfeeding problems.

In seven cases nipple retraction was present at diagnosis; seven other patients developed nipple retraction during follow-up. The 25 patients with primary lesions observed the first symptoms from two days up to six months before consultation (median two weeks). Recurrent disease had subsequently to be treated in seven of them. For patients with recurrent disease without fistula the interval since first symptoms ranged from four to 96 months (median 15 months); for patients with fistula this interval was five to 192 months (median 36 months). The median age of the three groups of patients was 34,35 and 33 respectively.

There were 53 active smokers among the 60 cases with RSBA (Table 1). At diagnosis, 23 patients smoked 11-20 cigarettes per day and 30 patients smoked more than 20 cigarettes per day. One patient who was treated for a primary lesion had stopped smoking two years before ( 40 cigarettes per day). There were only six patients who never smoked.

Analysed by age group the frequency of current cigarette smoking for the control group (37.3\%) was very similar to that for the general population (35.5\%) as calculated from data collected in 1981."

The different diagnostic subgroups are represented on Table 1 according to median age and smoking habits. Cigarette smoking was rather infrequent, but did not differ from the general population in older age groups represented by patients treated for prolapsus and incontinence, benign gynaecological tumours and gynaecological bleeding. In addition excessive smoking was noted for the young patients hospitalized for gynaecological infections.

The following variables were similar in the cases and in the controls: parity and contraception by IUD; the two groups differed, but not significantly, in terms of oral contraception and frequency of nipple retraction and, significantly, for smoking habits (Table 2).

TABLE 1 Distribution of 60 cases of RSBA and 300 controls divided in diagnostic subgroups according to median age and making habits

\begin{tabular}{|c|c|c|c|c|c|c|}
\hline & $\begin{array}{c}\text { Toud } \\
\text { number }\end{array}$ & $\begin{array}{l}\text { Medinn } \\
\text { gge }\end{array}$ & 0 & $\begin{array}{l}\text { Cigare } \\
1-10\end{array}$ & $\begin{array}{l}\text { etces/day } \\
11-20\end{array}$ & $>20$ \\
\hline $\begin{array}{l}\text { Cases with RSBA } \\
\text { - Fira abscess } \\
\text { - Recurring abscess } \\
\text { - Fistula }\end{array}$ & $\begin{array}{l}25 \\
18 \\
17\end{array}$ & $\begin{array}{l}34 \\
35 \\
33\end{array}$ & $\begin{array}{r}4 \\
3 \\
-\end{array}$ & $\bar{z}$ & $\begin{array}{l}9 \\
8 \\
6\end{array}$ & $\begin{array}{r}12 \\
7 \\
11\end{array}$ \\
\hline Total cases & 60 & 34 & 7 & - & 23 & 30 \\
\hline $\begin{array}{l}\text { Controls } \\
\text { - Benign gynecological } \\
\text { tumour } \\
\text { - Benign breast tumour } \\
\text { - Prolapsus, incontinene } \\
\text { - Gynsecological . } \\
\text { blecding (benign) } \\
\text { - Sterility I and II } \\
\text { - Tubal sterilization } \\
\text { - Gynnecological } \\
\text { infections } \\
\text { - Ohen } \\
\end{array}$ & $\begin{array}{r}61 \\
25 \\
16 \\
26 \\
27 \\
60 \\
\\
70 \\
15 \\
\end{array}$ & $\begin{array}{l}42 \\
33 \\
59 \\
45 \\
31 \\
35\end{array}$ & $\begin{array}{l}46 \\
16 \\
16\end{array}$ & $\begin{array}{l}6 \\
1 \\
0 \\
3 \\
4 \\
4\end{array}$ & $\begin{array}{l}6 \\
6 \\
0 \\
1 \\
5 \\
7\end{array}$ & $\begin{array}{l}3 \\
2 \\
0\end{array}$ \\
\hline Toul controls & 300 & 34 & 188 & 33 & 45 & 34 \\
\hline
\end{tabular}

TABLE 2 Distribution of 60 cases of RSBA and 300 age-matched controls according to various characteristics

\begin{tabular}{|c|c|c|}
\hline \multirow[t]{2}{*}{ Charecteristics } & \multicolumn{2}{|c|}{ Frequedcy $\%$} \\
\hline & Cenes & Controls \\
\hline Nulliparous & 42 & 38 \\
\hline Oral contraceptive use $(<45 y)$ & 45 & 36 \\
\hline IUD $\quad(<45 y)$ & 21 & 22 \\
\hline Nipple retraction (at dingnosis) & 12 & 5 \\
\hline No smoking & 12 & 63 \\
\hline$>10$ cigarettes/day & 88 & 26 \\
\hline$>20$ cigarettes/day & so & 11 \\
\hline
\end{tabular}


The results of the multiple logistic regression are shown in Table 3 . The relative risk of RSBA for a light smoker and a heavy smoker in comparison to a nonsmoker is given in columns 1 and 2 , respectively. Columns 3 and 4 of Table 3 give the statistical significance of each of the variables analysed individually (column 3) and in addition to smoking habits (column 4). The influence of smoking remains always predominant (column 5). As age is a matching variable, we can only estimate the interaction between age and smoking habits; this interaction is not statistically significant $\left(X_{2}^{2}=1.9\right.$. The only variable, nipple retraction, which alone has some influence on the risk of RSBA $\left(X_{1}^{2}=4.3 ; p<0.05\right)$ does not show a statistically significant association with the risk of disease after allowing for the influence of smoking habits $\left(X_{1}^{2}=1.2\right)$. The reverse is not true $\left(X_{2}^{2}=65.6\right.$; $p<0.001$ ). As a last model, we have grouped all the variables of the upper section. Smoking habits keep their statistically significant association with the risk of RSBA; the other four variables do not show a statistical significance $\left(X_{4}^{2}=6.8\right)$. The relative risk of RSBA does not change with any of the cited variables, which exclude a confounding effect with these variables. The estimate of relative risk of RSBA, with 95\% confidence limits is $9.2(3.6-23.5)$ for a light smoker and 26.4 (9.9-70.2) for a heavy smoker in comparison to a non-smoker.

\section{DISCUSSION}

Our results show a significant correlation between smoking and the occurrence of subareolar breast abscess. This fact has as yet not been considered in the current views of pathogenesis of RSBA, and may be of some importance in this context.

This disorder is more frequently seen in younger women, ${ }^{6}$ an observation not only confirmed by our own findings, but also by other recent reports. ${ }^{1,38,9}$

Parity and lactation do not seem to be a pathogenic factor since in both the RSBA group and the controls approximately $41 \%$ were nulliparous.

Also nipple retraction as discussed by several authors ${ }^{11,16,0}$ does not seem to constitute a predominant factor in this disease since $77 \%$ of our patients had neither nipple retraction at diagnosis nor developed nipple retraction during follow-up.

Nipple retraction should probably be considered as a consequence of RSBA since it was observed in only $8 \%$ of patients with first abscess, in $22 \%$ of patients with recurrent disease and in $47 \%$ of patients with fistula.

Ninety per cent of our patients had been exposed to cigarette smoke for many years before the breast disorder became manifest. Even the youngest patient had a history of at least three years of heavy cigarette smoking before the onset of the first symptoms. The impact of cigarette smoking on this disorder becomes most evident in the group of patients with periareolar fistula (Table 1).

Although the present data only suggest a causal relationship between smoking and RSBA, it is tempting to speculate that cigarette smoking has either a direct toxic effect on the retroareolar lactiferous ducts or an indirect effect via hormonal stimulation of breast secretion. As non-lactating breast glands secrete and absorb breast fluid the squamous metaplasia of the ductal epithelium and the subsequent inflammatory reactions could be induced by an accumulation of toxic exogenous substances resulting from cigarette smoking.

On the other hand slightly elevated, 8,8, 1,20 and in a few cases clearly pathological, prolactin levels

TABLE 3 Estimated relative rist for smaking habits versus no smaking and other passible variables assaciated with RSBA

\begin{tabular}{|c|c|c|c|c|c|}
\hline \multirow{3}{*}{$\begin{array}{l}\text { Model } \\
\text { Other variables }\end{array}$} & \multirow{2}{*}{\multicolumn{2}{|c|}{$\begin{array}{l}\text { Extimited } \\
\text { relstive risk }\end{array}$}} & \multicolumn{3}{|c|}{$\mathrm{X}^{2}$ tent for inclusion in the model } \\
\hline & & & \multirow{2}{*}{$\begin{array}{l}\text { Other specified } \\
\text { variables alone (df) } \\
\text { (3) }\end{array}$} & \multirow{2}{*}{$\begin{array}{c}\text { Of other specified } \\
\text { variables (df) } \\
\text { (4) }\end{array}$} & \multirow{2}{*}{$\begin{array}{c}\text { Smoking habits } \\
\text { (df = 2) } \\
\text { (S) }\end{array}$} \\
\hline & $\begin{array}{c}1-20 \text { cig } \\
\text { (1) }\end{array}$ & $>\underset{\text { (2) }}{21}$ cig & & & \\
\hline 1. & 9.2 & 26.4 & $69.3(2)^{*+*}$ & - & - \\
\hline 2. Interaction age + smoking & 7.5 & 25.6 & - & $1.9(2)$ & - \\
\hline 3. Nipple retraction & 9.1 & 25.3 & $4.3(1)^{*}$ & $1.2(1)$ & $65.6^{* * *}$ \\
\hline 4. Parity & 9.5 & 28.3 & $0.3(1)$ & $0.6(1)$ & $68.9 * * *$ \\
\hline 5. Oral contraception use & 9.1 & 26.3 & $2.1(1)$ & $0.5(1)$ & $68.4 * * *$ \\
\hline 6. IUD & 9.2 & 26.4 & $0.1(1)$ & $0.0(1)$ & $69.4^{* * *}$ \\
\hline $\begin{array}{l}\text { 7. Nipple retraction, parity, oral } \\
\text { contracepuive use, IUD) }\end{array}$ & 9.2 & 26.7 & $6.8(4)$ & $2.0(4)$ & $64.1 * * *$ \\
\hline
\end{tabular}

$p<0.05 * p<0.01 * * p<0.001$

- 'Resitual' effect due to smoking habits after inchuding the other specified variables in the model.

b 'Residual' effect due to other specified variables after including smoking habits in the model.

(df) Number of degrees of freedom in parenthesis. 
observed in patients suffering from RSBA could corroborate an abnormal stimulation of the breast. Both hypotheses could explain the recurrent aspect of the disease.

Certain neurotropic agents and oral contraceptives induce an elevation of plasma prolactin and were therefore considered as a possible cause of RSBA. ${ }^{18,19}$ In our series of 48 patients under 45 years old with RSBA who smoke, 25 (52\%) used oral contraceptives. However, of 106 women under 45 years old of the control group who smoke, 52 (49\%) also used oral contraceptives. The low rate of $26 \%$ of oral contraceptive users in the 163 non-smoking controls under 45 years old suggests a relationship between oral contraception and cigarette smoking and may reflect a different social behaviour.

The very strong association of cigarette smoking and RSBA counterbalances possible bias introduced by the retrospective analysis and by the hospital control group. The number of cigarettes smoked by the patients suffering from RSBA was significantly higher compared to all diagnostic subgroups of the control patients. Even though pathogenesis of RSBA is still not established cigarette smoking seems to be at least an important promoter of recurrent subareolar breast abscess.

\section{REFERENCES}

1 Johnsen C. Recurring subareoler abscess. Acta Chir Soand 1976; 142: 393.

2 Johnsen $C$. Inflammatory lesions of the breast. In: Strombeck J $O$, Rosto F E, eds. Surgery of the breast. New York, Thieme Inc, 1986: 48-52.

${ }^{3}$ Hangensen C D. Disease of the breast. Third edition. W B Saunders Company, Philadelphis, 1986, p 386-8.

4 Patey D H, Theckray A C. Pathology and treatment of mammary-duct fistula. Lancet 1958; 2: 871.
'Toker C. Lactiferous duct fistula. I Pathol Bacterial 1962; 84: 143.

${ }^{6}$ Kleinfeld G. Chromic ubareolar brear abscess. I Fl Med Assoc 1966; 53: 21.

1 Habif D, Perzin K, Lattes R. Subareolar association with squamous metaplasia. Am J Surg 1970; 119: 523-6.

- Peters F, Geisthovel F, Schulze-Tollen J, Pfleiderer A, Breckwoldt M. Die non-puerperale Mastitis. DHW 1985; 110: 97-104.

${ }^{2}$ Leach R D, Eykyn S J. Phillips I, Corrin B. Anserobic subareolar breast abscess. Larces 1979; 2: 35-7.

10 Pearzon H E. Bucteroides in areolar breast abacesces. Surg Gmec Obsze 1967; 125: 800 .

" Carwell H T, Burneth W E. Chronic rocurrent breast abscess secondary to inversion of the nipple. Surg Gynec Obstes 1956; 102: 439-42.

12 Heagensen C D. Mammary duct ectusix. A disease that may simulate carcinoms. Cancer 1951; 4: 749.

${ }^{13}$ Keaster E, Woolach Y. Granulomatous mestitis. A lesion clinically simulating carcinoma. Am J Clin Pathol 1972; S8: 642.

14 Abelin Th, Muller R. Trend der Reuchgewohnheiten in der Schweiz 1975-1981. Medecine Sociale a Prtventive 1985; 30: 95-99.

is Brestow N E, Day N E. Statistical methods in cancer research. Vol 1: The analysis of case-control studies. Arch Scientific Publications 32. Lyon, 1980.

16 Bonser G M, Dosseth J A, Jull J W. Human and experimental breas cancer. London; Pitman Medical, 1961.

17 Rees B I, Gravelle I H, Hughes L E. Nipple retraction in ductectasia. Br J Surg 1977; 64: 577-80.

Is Puelo J G, Ory S J. Nonpuerperal mastitis ascocirted with galuetorthen. Obset and Gynec 1983; 61: 69S-70S.

19 Peters F, Breckwold, M. Nompuerperac Mastitis bei bormonell timulierter Mamms. Geburtsh " Frawenheilk 1978; 38: $754-7$.

20 Pahnke V G, Kitschke H J, Bernauer M, Koll R. Mastitis nonpuerperalis - eine Estrankung mit zunehmender klinischer Relevanz? Geburtsh \& Freuenheilk 1985; 45: 29-35.

(Revised version received January 1988) 